\title{
Herpes zoster pericarditis
}

\author{
C R WINFIELD ${ }^{1}$ AND S P JOSEPH \\ From the Cambridge Military Hospital, Aldershot; and the Middlesex Hospital, London
}

SUMMARY A healthy 22-year-old man developed acute varicella pericarditis, characterised by an enanthem with diagnostic rising titres of varicella zoster antibodies but without the typical exanthem. This, the third reported case of varicella pericarditis, is the first to be documented without a typical varicella eruption.

Pericarditis and myocarditis are well-known complications of viral infections. These include Coxsackie B viruses, Coxsackie A viruses, Echoviruses, notably types 3,6 , and 19 , influenza virus, Epstein-Barr virus, and polio virus (Bennett and Forbes, 1967; Bell and Grist, 1970; Grist, 1972; Haynes et al., 1972; Shapiro et al., 1973; Sainani et al., 1975). Pericarditis may follow smallpox vaccination (Bengtsson et al., 1966; Matthews and Griffiths, 1974). Though varicella myocarditis has been reported (Hackel, 1953; Moore et al., 1969; Morales et al., 1971), only 2 cases of varicella pericarditis have been reported (Mandelbaum and Terk, 1959; Helmly et al., 1963). In both cases the pericarditis followed a typical varicella exanthem; this case is unique in that the typical rash was absent and the cardiac manifestations dominated the clinical picture.

\section{Case report}

A 22-year-old man, previously healthy, woke with discomfort in the upper chest, which, within a few hours, developed into severe central chest pain with dyspnoea and paraesthesiae in his fingers. On admission he was distressed, pale, and sweating, with a fever of $38.3^{\circ} \mathrm{C}$. No other abnormality was noted; the heart sounds were normal and there was no pericardial friction rub.

Routine biochemical and haematological investigation was normal except for a white blood cell count of $14.9 \times 10^{9} / 1$. Chest $x$-ray film was normal but the electrocardiogram showed prominent elevation of the ST segments in leads II, III, aVF, V5 and 6 (Fig.). An initial-diagnosis of inferolateral myocardial infarction was made. On the second day

'Present address: The Brompton Hospital, Fulham Road, London SW3. his temperature rose to $40^{\circ} \mathrm{C}$ and he developed severe painful ulcers in the left mandibular buccal sulcus associated with enlarged and tender cervical lymph glands. The white blood cell count was $11.9 \times 10^{9} / 1$ (61\% polymorphs and $35 \%$ lymphocytes). A pericardial friction rub was heard on the third day and his temperature became normal on the fifth day. Serum aspartate transaminase rose to $62 \mathrm{IU} / 1$ and the hydroxybutyric-dehydrogenase to $176 \mathrm{IU} / 1$ on the second day (normal values in the laboratory being 40 and $150 \mathrm{IU} / 1$, respectively). The ST segment elevation of the electrocardiogram resolved by the third day, with subsequent $T$ wave inversion in the same leads (Fig.).

Clinical recovery was uneventful. Virus serology showed a fivefold rise in herpes zoster complementfixing antibodies from 4 to 128 and a similar, anamnestic, rise in herpes simplex antibodies (Table).

In view of the patient's youth, it was important to exclude coronary heart disease. As the electrocardiographic findings were compatible with either pericarditis or myocardial infarction, coronary arteriography was performed; this showed a normal coronary vascular tree without coronary artery disease and with normal left ventricular function. The electrocardiogram returned to normal after 5 months (Fig.), and the patient remains in good health 3 years later with no recurrence of pain, other cardiac symptoms, or electrocardiographic abnormalities.

\section{Discussion}

The association of varicella infection and myocarditis has been previously reported and has a high mortality probably because of systemic infection (Hackel, 1953; Moore et al., 1969; Morales et al., 1971). Varicella with pericarditis alone is rare. The only two previously reported patients (Mandelbaum and 
Table Titres of viral complement-fixing antibodies

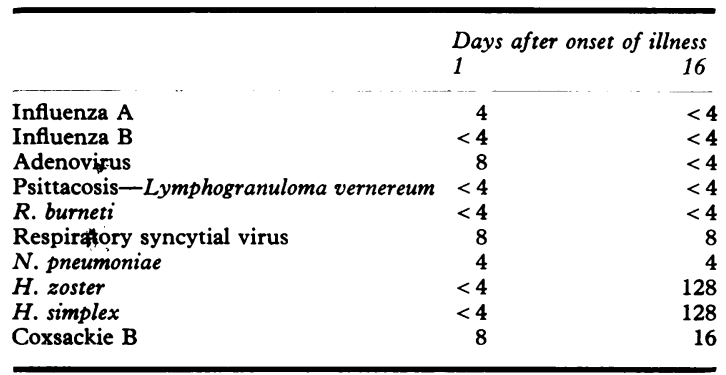

Terk, 1959; Helmly et al., 1963) were young men. As both had typical varicella eruptions, the clinical diagnosis of varicella was straightforward. This case had an enanthem and a history of chest pain only. The electrocardiographic changes initially suggested myocardial infarction but the elimination of coronary disease and the raised antibody titres permitted correct diagnosis.

Although this patient lacked the characteristic cutaneous eruption of herpes zoster, the mouth ulcers noted in the early phase of the illness were probably a zoster eruption in the territory of the buccal nerve, a branch of the third division of the trigeminal nerve. The rise in complement-fixing antibodies was diagnostic of herpes zoster infection according to the criteria of Grist (1972), with an anamnestic rise in herpes simplex antibodies.

A review of findings in infants with varicella has suggested that electrocardiographic abnormalities may be more common than is usually suspected (Paci et al., 1960). It is possible that pericardial or myocardial involvement in the absence of clinical symptoms may occur frequently and has been postulated in several viral illnesses (Ahlborg et al., 1966; Lewes et al., 1974). This case suggests that a rising titre of varicella antibodies in the viral serological screening of patients with acute benign pericarditis may increase the frequency with which varicella infection is diagnosed.

We thank Dr J M Hinton of St Richard's Hospital, Chichester, Dr Walter Somerville, and Brigader $\mathrm{H} S$ Moore for permission to publish details of this case.

\section{References}

Ahlborg, B., Linroth, K., and Nordgren, B. (1966). ECGchanges without subjective symptoms after smallpox vaccination of military personnel. Acta Medica Scandinavica, Suppl. 464, 127-134.

Bell, E. J., and Grist, N. R. (1970). Echoviruses, carditis and acute pleurodynia. Lancet, 1, 326-328.

Bengtsson, E., Holmgren, A., and Nystrom, B. (1966). Circulatory studies in patients with abnormal ECG in the course of postvaccinial complications. Acta Medica Scandinavica, Suppl. 464, 113-126.

Bennett, N. McK., and Forbes, J. A. (1967). Coxsackie pericarditis. American Heart fournal, 74, 435-436.

Grist, N. R. (1972). Viruses and myocarditis. Postgraduate Medical fournal, 48, 750-753.

Hackel, D. B. (1953). Myocarditis in association with varicella. American fournal of Pathology, 29, 369-379.

Haynes, R. E., Cramblett, H. G., Hilty, M. D., Azimi, P. H., and Crews, J. (1972). ECHO virus type 3 infections in children: clinical and laboratory studies. Fournal of Pediatrics, 80, 589-595.

Helmly, R. B., Smith, J. O., jun, and Eisen, B. (1963). Chickenpox with pneumonia and pericarditis. Fournal of the American Medical Association, 186, 870-872.

Lewes, D., Rainford, D. J., and Lane, W. F. (1974). Symptomless myocarditis and myalgia in viral and Mycoplasma pneumoniae infections. British Heart fournal, 36, 924-932.

Mandelbaum, T., and Terk, B. H. (1959). Pericarditis in association with chickenpox. Fournal of the American Medical Association, 170, 191-194.

Matthews, A. W., and Griffiths, I. D. (1974). Post-vaccinial pericarditis and myocarditis. British Heart fournal, 36, 1043-1045.

Moore, C. M., Henry, J., Benzig, G. III, and Kaplan, S. (1969). Varicella myocarditis. American Fournal of Diseases of Children, 118, 899-902.

Morales, A. R., Adelman, S., and Fine, G. (1971). Varicella myocarditis. A case of sudden death. Archives of Pathology, 91, 29-31.
Fig. Electrocardiographic changes showing $S T$ segment elevation on day 1 , maximum $T$ wave inversion on day 17 , and the return to normal after 5 months

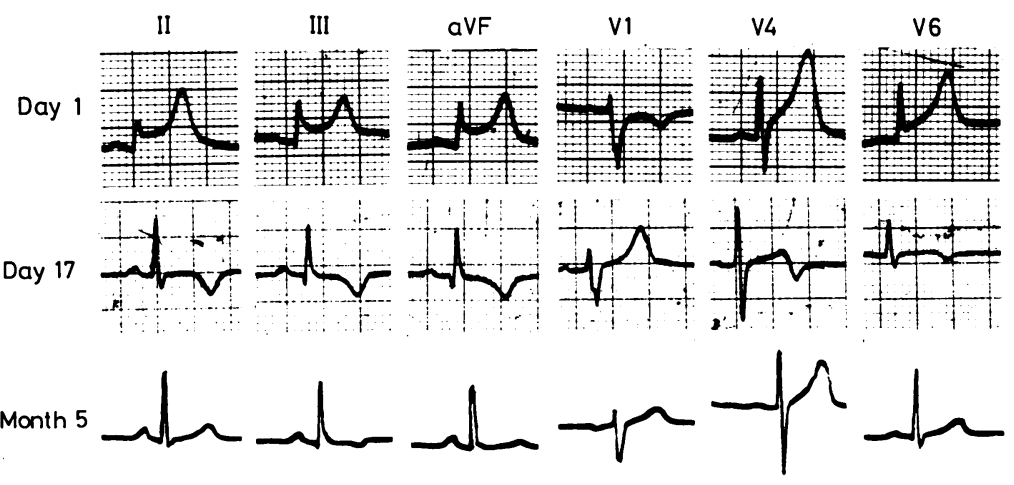


Paci, A., Giorgi, P. L., and Vizzoni, L. (1960). Studio elettrocardiografico in corso di varicella nell'infanzia. Rivista di Clinica Pediatrica, 66, 333-338.

Sainani, G. S.. Dekate, M. P., and Rao, C. P. (1975). Heart disease caused by Coxsackie virus $\mathrm{B}$ infection. British Heart fournal, 37, 819-823.

Shapiro, S. C., Dimich, I., and Steier, M. (1973). Pericarditis as the only manifestation of infectious mononucleosis. American fournal of Diseases of Children, 126, 662-663.

Requests for reprints to Dr S P Joseph, Department of Cardiology, Mayday Hospital, Thornton Heath, Surrey CR4 7YE. 